\title{
Abundance and distribution of Macrolide- Lincosamide-Streptogramin resistance genes in an anaerobic-aerobic system treating spiramycin production wastewater
}

\author{
Miaomiao Liu ${ }^{a}$, Ran Ding ${ }^{a}$, Yu Zhang ${ }^{a, *}$, Yingxin Gao ${ }^{a}$, Zhe Tian ${ }^{a}$, \\ Tong Zhang ${ }^{b}$, Min Yang ${ }^{a}$ \\ a State Key Laboratory of Environmental Aquatic Chemistry, Research Center for Eco-Environmental Sciences, \\ Chinese Academy of Sciences, P.O. Box 2871, Beijing 100085, China \\ $\mathrm{b}$ Environmental Biotechnology Laboratory, Department of Civil Engineering, The University of Hong Kong, \\ Hong Kong SAR, China
}

\section{A R T I C L E I N F O}

Article history:

Received 15 January 2014

Received in revised form

20 May 2014

Accepted 24 May 2014

Available online 16 June 2014

Keywords:

Spiramycin wastewater

Anaerobic and aerobic biological treatment

Macrolide-Lincosamide-Streptogra-

min resistance genes

Mobile elements

\begin{abstract}
A B S T R A C T
The behaviors of the Macrolide-Lincosamide-Streptogramin (MLS) resistance genes were investigated in an anaerobic-aerobic pilot-scale system treating spiramycin (SPM) production wastewater. After screening fifteen typical MLS resistance genes with different mechanisms using conventional PCR, eight detected genes were determined by quantitative PCR, together with three mobile elements. Aerobic sludge in the pilot system exhibited a total relative abundance of MLS resistance genes (per 16S rRNA gene) 2.5 logs higher than those in control samples collected from sewage and inosine wastewater treatment systems $(P<0.05)$, implying the presence of SPM could induce the production of MLS resistance genes. However, the total relative gene abundance in anaerobic sludge $\left(4.3 \times 10^{-1}\right)$ was lower than that in aerobic sludge $\left(3.7 \times 10^{\circ}\right)$ despite of the higher SPM level in anaerobic reactor, showing the advantage of anaerobic treatment in reducing the production of MLS resistance genes. The rRNA methylase genes $(\operatorname{erm}(\mathrm{B}), \operatorname{erm}(\mathrm{F}), \operatorname{erm}(\mathrm{X}))$ were the most abundant in the aerobic sludge $\left(5.3 \times 10^{-1}-1.7 \times 10^{\circ}\right)$, followed by esterase gene ere $(\mathrm{A})$ $\left(1.3 \times 10^{-1}\right)$ and phosphorylase gene $m p h(B)\left(5.7 \times 10^{-2}\right)$. In anaerobic sludge, erm $(\mathrm{B})$, erm $(\mathrm{F})$, ere(A), and $m s r(D)$ were the major ones $\left(1.2 \times 10^{-2}-3.2 \times 10^{-1}\right)$. These MLS resistance genes (except for $m s r(D))$ were positively correlated with Class 1 integron $\left(r^{2}=0.74-0.93, P<0.05\right)$, implying the significance of horizontal transfer in their proliferation.
\end{abstract}

(c) 2014 Elsevier Ltd. All rights reserved.

\footnotetext{
* Corresponding author. Tel.: +8610 62923475; fax: +86 1062923541.

E-mail addresses: lmmhit@163.com (M. Liu), d80_0@sohu.com (R. Ding), zhangyu@rcees.ac.cn (Y. Zhang), gyx@rcees.ac.cn (Y. Gao), tianzhescu@163.com (Z. Tian), zhangt@hku.hk (T. Zhang), yangmin@rcees.ac.cn (M. Yang).
} http://dx.doi.org/10.1016/j.watres.2014.05.045

0043-1354/@ 2014 Elsevier Ltd. All rights reserved. 


\section{Introduction}

Antibiotic production generates waste streams with high concentrations of chemical oxygen demand $\left(\mathrm{COD}_{\mathrm{Cr}}\right)$, residual antibiotics and ammonium, which are, in general, treated by biological processes (Larsson et al., 2007; Ma et al., 2009). However, high antibiotic concentrations and bacterial densities in biological wastewater systems may favor the proliferation of antibiotic resistance genes (ARGs), which could pose health risks to humans via various pathways (Li et al., 2010; Munir et al., 2011; Zhang et al., 2013). Our previous study has revealed that large amounts of tetracycline resistance genes were generated during aerobic treatment of oxytetracycline (OTC) production waste stream (Liu et al., 2012). On the other hand, the anaerobic process has been widely used for the treatment of industrial wastewater containing high concentration of $\mathrm{COD}_{\mathrm{Cr}}$ (Lettinga, 1995). At the same time, anaerobic digestion of excess sludge has been found to effectively reduce ARGs (Diehl and Lapara, 2010). However, the behaviors of ARGs during anaerobic wastewater treatment processes under high antibiotic levels have been seldom reported.

Macrolides, which could inhibit a wide range of bacteria, are a group of antibiotics frequently used in clinics and feedlots (Iacoviello and Zinner, 2002). Macrolides share an overlapping binding site on bacterial ribosome with structurally distinct lincosamides and streptogramins, leading to clusters of genes encoding resistance to these antibiotics, called Macrolide-Lincosamide-Streptogramin (MLS) resistance genes (Sutcliffe and Leclercq, 2002). MLS resistance could be divided into three groups according to their resistance mechanisms: rRNA methylase genes, efflux genes, and enzymatic modification genes (Roberts et al., 1999). To date, 79 MLS resistance genes have been identified in a variety of gram-positive and gram-negative bacteria from human and animal origins (http://faculty.washington.edu/marilynr/). Recently, the occurrence of MLS resistance genes has gained increasing concerns. Chen et al. (2007) and Koike et al. (2010) surveyed rRNA methylase genes in swine feedlot environment and found that erm(B) and erm(F) had the highest relative abundance. Negreanu et al. (2012) reported that the relative abundances of $\operatorname{erm}(\mathrm{B})$ and $\operatorname{erm}(\mathrm{F})$ were at the levels of $10^{-4}-10^{-3}$ in the raw influent and aerobic sludge of sewage treatment plants. However, the behaviors of MLS resistance genes during the treatment of macrolide production wastewater with high antibiotic levels have not yet been clarified.
In this work, we surveyed the occurrence, abundance, and distribution of MLS resistance genes in a pilot-scale biological system consisting of anaerobic, anoxic, and aerobic units in succession to treat spiramycin production waste stream (SPM wastewater) and its mixture with two other antibiotic production waste streams (paromomycin and ribostamycin) over a period of 9 months. Fifteen MLS resistance genes, which conduct different resistance mechanisms and have been reported in the environment previously, were screened by conventional PCR. Eight detected genes (erm(B), erm(F), erm(T), $\operatorname{erm}(\mathrm{X}), \operatorname{msr}(\mathrm{D}), \operatorname{mef}(\mathrm{A})$, ere(A), $m p h(\mathrm{~B}))$ were determined using quantitative PCR (qPCR), together with three mobile elements (intI1, ISCR1, and Tn916/1545). At the same time, clone libraries were constructed to analyze bacterial compositions and diversities of MLS resistance genes. This study will help understand the fate of ARGs during anaerobic and aerobic wastewater treatment of high antibiotic levels.

\section{Materials and methods}

\subsection{Pilot-scale wastewater treatment systems and sampling}

SPM is a 16-member macrolide widely used in veterinary clinics. Samples were taken from a pilot-scale SPM wastewater treatment system consisting of sequential up-flow anaerobic sludge bed (UASB), anoxic reactor, and oxic reactor (Fig. 1). The effective reactor volumes of the three reactors were $600 \mathrm{~L}, 200 \mathrm{~L}$, and $400 \mathrm{~L}$, respectively. The flow rate of raw wastewater was $200 \mathrm{~L} / \mathrm{d}$. The hydraulic retention time (HRT) was $48 \mathrm{~h}$ for UASB and oxic reactors, and $24 \mathrm{~h}$ for the anoxic reactor. The UASB effluent was recirculated to the inlet at a dilution ratio of 2:1 (flow rate ratio of UASB effluent to raw wastewater). The mixed liquor from the oxic reactor was recirculated to the anoxic reactor at a ratio of 2:1 (flow rate ratio of oxic effluent to UASB effluent). Sludge from the sedimentation tank was returned to the anoxic reactor at a ratio of 1:1. Sludge from a citrate production wastewater treatment plant and a sewage treatment plant was inoculated into the UASB reactor at a volume ratio of 1:1. Inoculum for the anoxic and oxic reactors (A/O reactors) was collected from a full-scale SPM wastewater treatment plant in Jiangsu Province. The operation of the system was divided into three stages: receiving (i) SPM wastewater, (ii) mixture of SPM wastewater and paromomycin wastewater, and (iii) mixture of SPM

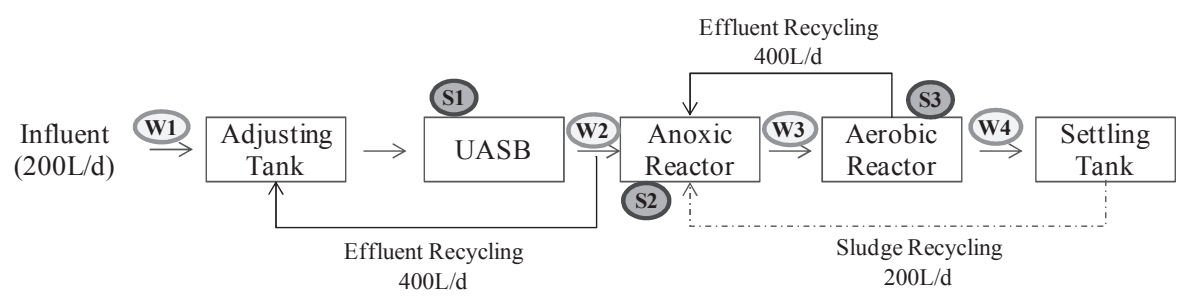

Fig. 1 - Scheme of the SPM wastewater treatment systems and sampling sites. UASB: Up-flow Anaerobic Sludge Bed Reactor. W1, W2, W3, W4: Raw influent and effluent from UASB, Anoxic, and Aerobic reactors. S1, S2, S3: Sludge from the UASB, Anoxic, and Aerobic reactors, respectively. $S 1_{1}-S 3_{1} ; \mathbf{S 1}_{2}-\mathbf{S} 3_{2} ; \mathbf{S 1}_{3}-\mathbf{S} 3_{3}$ : sludge samples from the three stages treating spiramycin, spiramycin and paramomycin, spiramycin and ribostamycin, respectively. 
wastewater and ribostamycin wastewater. Each stage lasted for three months.

Wastewater and sludge samples were collected to study the occurrence, abundance and distribution of MLS resistance genes in different treatment processes. Raw wastewater and effluent from each treatment unit (W1-W4) were collected every $6 \mathrm{~h}$ four times at the end of each stage, and nine sludge samples were collected from each reactor (S1-S3) once at the end of each stage $\left(\mathrm{S}_{1}-\mathrm{S} 3_{1}, \mathrm{~S} 1_{2}-\mathrm{S} 3_{2}\right.$, and $\mathrm{S} 1_{3}-\mathrm{S} 3_{3}$ for the three stages, respectively) (Fig. 1). The SPM fermentation residue (SPM-FR) was collected directly from the production facilities after SPM extraction and dehydration. For comparative study, two sludge samples, STP-AS (mixture of aerobic sludge from two sewage treatment plants located in Beijing and Tianjin, respectively) and Control-AS (sludge from an inosine production wastewater treatment system in Xinxiang City, Henan Province) were used as controls. All samples were transported to the lab at $4{ }^{\circ} \mathrm{C}$ and treated within $24 \mathrm{~h}$.

\subsection{Chemical analysis methods}

$\mathrm{COD}_{\mathrm{Cr}}$, ammonia, total nitrogen, and total phosphate were determined according to the National Standard Methods of China (Table A1) (Wei, 2002). The concentrations of SPM in wastewater and sludge were determined using ultra performance liquid chromatography tandem mass spectrometry (UPLC-MS/MS, Waters, USA), with detailed procedures described in Supplementary Information (Table A2).

\subsection{DNA extraction}

For each sludge sample, $1 \mathrm{~mL}$ of mixed liquor was centrifuged at $12,000 \times \mathrm{g}$ for $10 \mathrm{~min}$ at $4{ }^{\circ} \mathrm{C}$. Then $0.25 \mathrm{~g}$ sediment (wet weight) after centrifugation was used for DNA extraction by a FastDNA SPIN kit for soil (Qbiogene, Solon OH). The DNA solution volume was $80 \mu \mathrm{L}$, among which $2 \mu \mathrm{L}$ was used for concentration determination by NanoDrop ND-1000 (USA) and $5 \mu \mathrm{L}$ was checked by electrophoresis on a $1 \%$ (weight/volume) agarose gel.

\section{4. $\quad P C R$ and quantitative PCR}

Fifteen MLS resistance genes including eight rRNA methylase genes $(\operatorname{erm}(\mathrm{A}), \operatorname{erm}(\mathrm{B}), \operatorname{erm}(\mathrm{C}), \operatorname{erm}(\mathrm{F}), \operatorname{erm}(\mathrm{G}), \operatorname{erm}(\mathrm{Q}), \operatorname{erm}(\mathrm{T})$, $\operatorname{erm}(\mathrm{X}))$, three efflux genes $(\operatorname{msr}(\mathrm{A}), \operatorname{msr}(\mathrm{D}), \operatorname{mef}(\mathrm{A}))$, two esterase genes (ere $(\mathrm{A})$, ere $(\mathrm{B}))$, two phosphorylase genes $(m p h(A), m p h(B))$, and three mobile elements associated with MLS resistance genes (Class 1 integron (intI1), transposon Tn916/1545, the first group of insertion sequence common region (ISCR1)) were tested with primers listed in Table A3. The PCR assays were carried out for SPM-FR and all sludge samples from the SPM wastewater treatment systems, with sterile water used as the negative control. The PCR assays were conducted in $25 \mu \mathrm{L}$ volume reactions using an ABI PCR System 9700 (ABI, USA). The PCR mixture consisted of $1 \times \mathrm{Ex}$ Taq buffer, 5 nM dNTP, 0.625 U Ex Taq (Takara, Japan), 400 nM each primer, $0.5 \mathrm{mg} \mathrm{mL}^{-1} \mathrm{BSA}$, and 1-2 $\mu \mathrm{L}$ DNA. The temperature program consisted of initial denaturation at $95^{\circ} \mathrm{C}$ for $5 \mathrm{~min}$, followed by 35 cycles of $30 \mathrm{~s}$ at $95^{\circ} \mathrm{C}, 30 \mathrm{~s}$ at different annealing temperatures (Table A3) and extension at $72{ }^{\circ} \mathrm{C}$ for
$45 \mathrm{~s}$, and finished with a final extension step at $72{ }^{\circ} \mathrm{C}$ for $7 \mathrm{~min}$. PCR products were checked by electrophoresis on $1 \%$ (weight/ volume) agarose gel in $1 \times$ TBE buffer (Table A4). For each detected gene, the positive amplicons were further assured by cloning and sequencing.

Eight detected MLS resistance genes $(\operatorname{erm}(B), \operatorname{erm}(\mathrm{F}), \operatorname{erm}(\mathrm{T})$, $\operatorname{erm}(\mathrm{X}), \operatorname{msr}(\mathrm{D}), \operatorname{mef}(\mathrm{A})$, ere(A), $m p h(\mathrm{~B}))$, three detected mobile elements (intI1, ISCR1, Tn916/1545), and the 16S rRNA genes were quantified for all samples using SYBR-Green real-time qPCR, with the same primers as conventional PCR. Standard plasmids carrying target genes were obtained by TA clones and extracted using a TIANpure Mini Plasmid kit (Tiangen, China). Concentrations of the standard plasmids (ng $\mu \mathrm{L}^{-1}$ ) were determined with the Nanodrop ND-1000 (Nanodrop, USA) and converted to the measurement of copies $\mu \mathrm{L}^{-1}$ (Liu et al., 2012). The $25 \mu \mathrm{L}$ reactions typically contained $1 \times$ Sybr Green I, $1 \times$ Dye (Takara), $200 \mathrm{nM}$ each primer, $0.5 \mathrm{mg} \mathrm{mL}^{-1}$ BSA, and $2 \mu \mathrm{L}$ DNA templates. Real-time PCR was run using an ABI 7300 apparatus (ABI, USA) by the following program: $95^{\circ} \mathrm{C}$ for $30 \mathrm{~s}, 40$ cycles consisting of: (i) $95^{\circ} \mathrm{C}$ for $10 \mathrm{~s}$, (ii) annealing temperature for $15 \mathrm{~s}$ (Table A3), (iii) $72^{\circ} \mathrm{C}$ for $15 \mathrm{~s}$, and (iv) $78^{\circ} \mathrm{C}$ for $26 \mathrm{~s}$ to collect the fluorescent signals. The melting process was automatically generated by the ABI 7300 software. All standards, samples, and negative control (sterile water) were quantified in triplicates. To prevent the inhibition of the sample matrix, 10-100 fold diluted samples were used for quantification. The following requirements were satisfied to obtain reliable quantification (Table A5): $R^{2}$ was higher than 0.99 for standard curves over 5 orders of magnitude. Amplification efficiencies based on slopes were between $90 \%$ and $110 \%$. The specificity was assured by the melting curves and gel electrophoresis. The minimum quantification limits for all genes were in the range of $1.0 \times 10^{2}$ to $2.1 \times 10^{3}$ copies per $\mu \mathrm{L}$ DNA.

The absolute abundances of MLS resistance genes and mobile elements (gene copies per sample volume) were shown in Table A6. To minimize variances caused by different bacterial abundances, DNA extraction and quantification efficiencies, the relative abundances of MLS resistance genes and mobile elements were obtained by normalizing their copy numbers to those of the 16S rRNA genes (Fig. 2, Table A7). There were no significant differences among the three treatment stages $(P>0.05)$, which made it possible to calculate the average relative abundances of MLS resistance genes using the data of the three stages $\left(S 1_{\text {mean }}, \mathrm{S} 2_{\text {mean }}\right.$, and $\mathrm{S} 3_{\text {mean }}$ for anaerobic, anoxic, and aerobic sludge, respectively) (Table A6 and A7).

\subsection{Phylogenetic analysis of MLS resistance genes}

Phylogenetic diversities of all detected MLS resistance genes were analyzed by cloning for the anaerobic or aerobic sludge from the SPM wastewater treatment system, using the same primers as conventional PCR. The diversities of erm(B), ere(A), and $m s r(D)$, which represent three different resistance mechanisms, were determined for both anaerobic and aerobic sludge. The diversity of ere(A), which showed the highest diversity in both aerobic and anaerobic sludge, was also investigated for sludge samples from the sewage and inosine wastewater treatment systems (STP-AS and Control-AS) for 

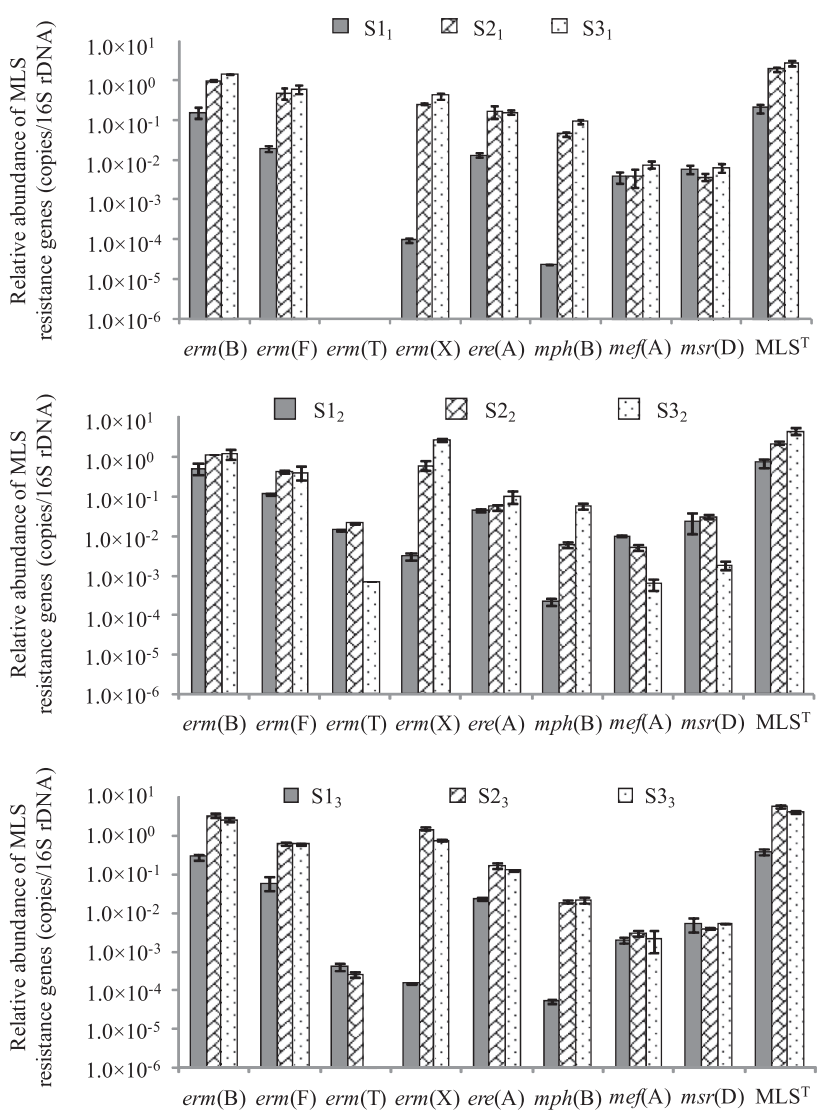

Fig. 2 - Relative abundance of MLS resistance genes in anaerobic, anoxic, and aerobic sludge during three different stages treating SPM $\left(\mathbf{S 1}_{1}-\mathbf{S}_{1}\right)$, SPM and paramomycin $\left(\mathrm{S1}_{2}-\mathbf{S} 3_{2}\right), \mathbf{S P M}$ and ribostamycin $\left(\mathrm{S1}_{\mathbf{3}_{3}}-\mathbf{S} 3_{3}\right)$. MLS $^{\mathrm{T}}$ : the total abundance of all determined MLS resistance genes.

comparison. The cloning process was the same as previously described (Liu et al., 2012). Sequences with identities lower than $98 \%$ (calculated by the software Lasergene version 7 (DNAStar, USA)) were clustered as different gene groups (Koike et al., 2007). One representative sequence was chosen from each group to construct neighbor-joining phylogenetic trees using the software Mega version 4.1 (http:// megasoftware.net/), together with sequences retrieved from NCBI GenBank (Fig. 3 and A2). The phylogenetic distributions of ere(A) in different systems are shown in Table 1. The MLS resistance gene sequences were deposited in NCBI GenBank under accession No. KC669391 to KC669407.

\subsection{Statistical analyses}

All statistical analyses were performed using SPSS version 15.0. Paired samples t-tests and P-values were used to assess significant differences between systems and samples. Pearson's bi-variate correlation analysis was used to assess correlations between MLS resistance genes and mobile elements in sludge samples from SPM wastewater treatment systems.

\section{Results}

\subsection{Chemical characteristics of wastewater and sludge}

As shown in Tables A1 and A2, the system exhibited $91.3 \%$ COD ${ }_{\text {Cr }}$ removal and 92.7-97.1\% SPM removal at three different stages. The concentration of $\mathrm{COD}_{\mathrm{Cr}}$ was $7193.4 \pm 424.3 \mathrm{mg} / \mathrm{L}$ in the influent, which decreased to $1431.2 \pm 56.4 \mathrm{mg} / \mathrm{L}$, $1000.0 \pm 35.4 \mathrm{mg} / \mathrm{L}$ and $615.2 \pm 62.7 \mathrm{mg} / \mathrm{L}$ following anaerobic, anoxic and aerobic treatment, respectively. The concentrations of SPM were at high levels $(12.4-41.8 \mathrm{mg} / \mathrm{L})$ in the influent (W1), and decreased to $1.8-3.8 \mathrm{mg} / \mathrm{L}$ and $0.9-3.0 \mathrm{mg} / \mathrm{L}$ after anaerobic (W2) and aerobic (W4) treatment, respectively. The SPM concentrations in sludge (S1-S3) were 110.3-289.4 mg/kg dry weight when influent (W1) SPM level was $41.0 \mathrm{mg} / \mathrm{L}$, and 24.5-149.6 mg/kg dry weight when influent (W1) SPM level was $12.4 \mathrm{mg} / \mathrm{L}$. The SPM concentration in the fermentation residue (SPM-FR) was $931.3 \mathrm{mg} / \mathrm{kg}$ dry weight.

\subsection{Occurrence of MLS resistance genes}

As shown in Table A4, eight of the fifteen MLS resistance genes were detected in the sludge samples of the SPM wastewater

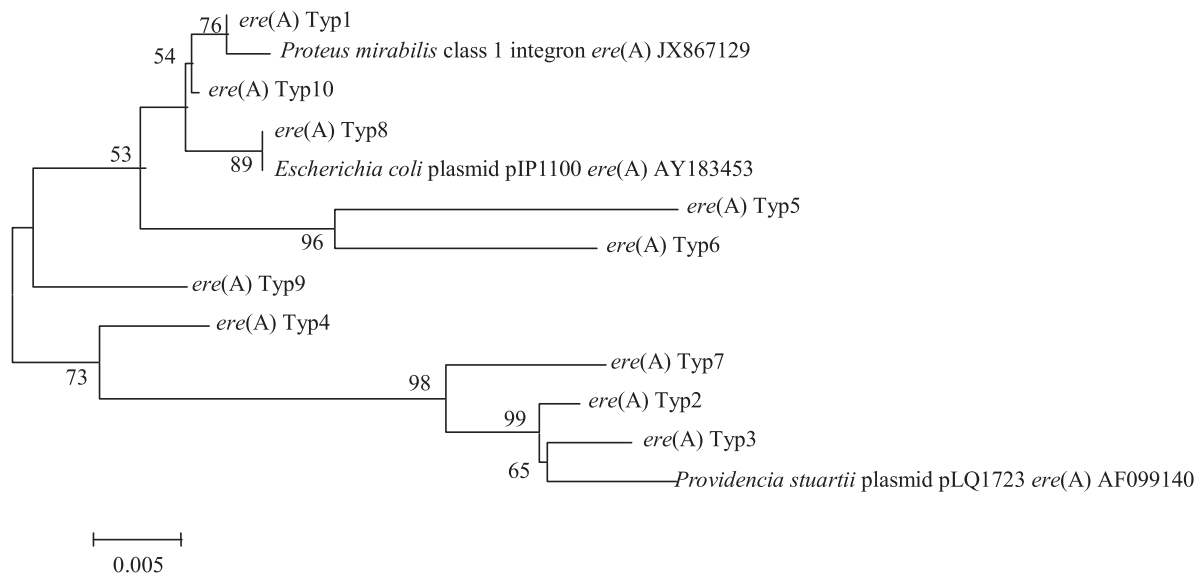

Fig. 3 - Neighbor-joining phylogenetic tree of ere(A) in sludge samples from SPM wastewater, sewage, and inosine wastewater treatment systems. 
Table 1 - Phylogenetic distribution of ere(A) in sludge samples from SPM wastewater (S1 and S3), sewage (STP-AS), and inosine production wastewater treatment systems (Control-AS).

Samples

Clones of each sequence type

\begin{tabular}{lcccccccccc} 
& Typ1 & Typ2 & Typ3 & Typ4 & Typ5 & Typ6 & Typ7 & Typ8 & Typ9 & Typ10 \\
\hline S1 & 2 & 20 & 1 & 1 & - & - & - & - & - & - \\
S3 & 16 & 4 & - & - & 1 & - & - & 1 & 1 & - \\
STP-AS & 20 & 2 & - & - & - & 1 & 1 & - & - & - \\
Control-AS & 18 & - & - & - & - & - & - & - & - \\
\hline "-": not detected. & & & & & & & & &
\end{tabular}

treatment system, including four rRNA methylases (erm(B), $\operatorname{erm}(\mathrm{F}) \operatorname{erm}(\mathrm{T}), \operatorname{erm}(\mathrm{X}))$, two efflux proteinase genes (mef(A), $m s r(D))$, one esterase gene ere(A), and one phosphorylase gene $(m p h(B))$. The rRNA methylase genes erm $(B)$ and erm $(F)$, and the esterase gene ere(A) were the most prevalent resistance genes detected in all sludge samples. rRNA methylase gene erm(X) and phosphorylase gene $m p h(B)$ were detected in all aerobic sludge, but less frequent in anaerobic sludge (2/3 and $1 / 3$, respectively). The rRNA methylase gene erm(T) and the efflux genes $m e f(A)$ and $m s r(D)$ were more frequently detected in the three anaerobic sludge (S1: $2 / 3-3 / 3)$ than those in the aerobic sludge (S3: 0/3). intI1 was detected in all sludge samples, while Tn916/1545 was more frequently detected in anaerobic sludge samples $(\mathrm{S} 1,3 / 3)$ than that in aerobic sludge (S3, 2/3). No MLS resistance genes or mobile elements were detected by conventional PCR in the SPM fermentation residue (SPM-FR).

\subsection{Relative abundance of MLS resistance genes and mobile elements}

As shown in Table A7, only erm(B), erm(F), erm(T), erm(X), and $m s r(D)$ were detected in SPM-FR with relative abundances between $7.0 \times 10^{-6}$ to $1.5 \times 10^{-3}$, which totally $\left(\mathrm{MLS}^{\mathrm{T}}\right)$ added up to $1.6 \times 10^{-3}$. The relative abundances of MLS resistance genes in anaerobic sludge $\left(\mathrm{S} 1_{\text {mean }}, 1.0 \times 10^{-4}-3.2 \times 10^{-1}\right)$ and aerobic sludge $\left(\mathrm{S} 3\right.$ mean, $\left.2.4 \times 10^{-4}-1.7 \times 10^{\circ}\right)$ were much higher than those in SPM-FR. By comparison, the relative abundances of the MLS resistance genes in the aerobic sludge samples from sewage and inosine wastewater treatment systems were much lower (STP-AS: undetectable-9.5 × 10 $0^{-3}$, Control-AS: undetectable- $8.2 \times 10^{-3}$ ). Since the inoculum for anaerobic treatment was collected from citrate wastewater and sewage treatment plants, it's assumed that the relative abundance of MLS resistance genes in the anaerobic seed sludge was comparable to that in the control systems.

Results showed that intI1 was abundant in aerobic sludge $\left(\mathrm{S} 3_{\text {mean }}, 1.3 \times 10^{\circ}\right)$, but less abundant in anaerobic sludge $\left(\mathrm{S} 1_{\text {mean }}, 1.2 \times 10^{-2}\right)$. The relative abundances of $\mathrm{Tn} 916 / 1545$ and ISCR1 were $8.8 \times 10^{-2}$ and $4.6 \times 10^{-5}$ in anaerobic sludge and $1.5 \times 10^{-2}$ and $1.4 \times 10^{-3}$ in aerobic sludge. Both intI 1 and Tn916/1545 were at low levels $\left(2.0 \times 10^{-6}\right.$ and $1.8 \times 10^{-4}$, respectively), and ISCR1 was below the detection limit in SPMFR.

\subsection{Cloning of bacterial 16S rRNA genes}

As shown in Table A8, gram-positive bacteria mainly composed of Firmicutes, were dominant in anaerobic sludge
(S1), accounting for $77.1 \%$ of the total bacteria. However, gram-negative bacteria, which were mainly composed of Alpha-proteobacteria (18.5\%) and Beta-proteobacteria (33.3\%), became dominant (96.2\%) in aerobic sludge (S3). All OTUs from the SPM-FR clone library were $99.6-100.0 \%$ identical to Streptomyces ambofaciens, the reported production bacteria of SPM (Sutcliffe and Leclercq, 2002).

\subsection{Diversity of MLS resistance genes}

The phylogenetic trees of all eight detected MLS resistance genes in sludge samples of the SPM wastewater treatment system are shown in Fig. 3 and Fig. A2. ere(A) exhibited the highest sequence diversity, with 10 different types (Typ1Typ10) detected (Table 1). Typ1 with $99 \%$ identity to ere(A) in Proteus mirabilis (JX867129) and Escherichia coli plasmid (AY183453) was the most abundant in all aerobic sludge samples $(16 / 23,20 / 24$ and 18/20 in S3, STP-AS and Control-AS, respectively). Typ2, which was $99 \%$ identical to ere(A) in Providencia stuartii plasmid (AF099140) and Enterobacter aerogenes (AF326209), was the most abundant in the anaerobic sludge samples (S1, 20/24). Typ3 to Typ10, which were $>95.5 \%$ identical to known ere(A) sequences, were sparsely distributed in different samples (only one clone for each type).

Conserved sequences of erm(B) with over $99 \%$ identity to those in Enterococcus faecalis (M11180)and Clostridium difficile (AJ294530) were found in anaerobic and aerobic sludge samples (S1 and S3), consistent with previous research showing that all erm(B) sequences obtained from swine lagoons and groundwater were over $99 \%$ identical to each other (Koike et al., 2010). For $m s r(D)$, most sequences (Typ1, 39/42) were identical to each other $(99.3 \%-100.0 \%)$ in anaerobic and aerobic sludge (S1 and S3), while three different sequences (Typ2) with lower identities (95.6\%-96.2\%) occurred only in anaerobic sludge. All $m s r(D)$ sequences were 96-97\% identical to those reported in the genome and transposons of Streptococcus, Bacteroides, Gardnerella, and Clostridium, etc. The other MLS resistance genes were very conservative in the aerobic sludge of the SPM wastewater treatment system, with high identities to each other ( $>99 \%)$.

\section{Discussion}

Till now, there have been a few reports about MLS genes in the environment. Chen et al. (2007) found that the relative abundances of $\operatorname{erm}(\mathrm{B}), \operatorname{erm}(\mathrm{F}), \operatorname{erm}(\mathrm{T})$, and $\operatorname{erm}(\mathrm{X})$ were in the range of $4.4 \times 10^{-4}-5.4 \times 10^{-2}$ and $7.4 \times 10^{-5}-4.3 \times 10^{-1}$ in swine 
manures and lagoons, respectively. Koike et al. (2010) reported a similar relative abundance of erm(B) $\left(4 \times 10^{-4}-10^{-2}\right)$ in swine lagoons. Marti et al. (2013) reported that the relative abundance of $\operatorname{erm}(\mathrm{B})$ was at the magnitude of $10^{-4}-10^{-3}$ in the biofilm and sediments of a sewage treatment system. Stoll et al. (2012) even found high prevalence of erm(B) in surface water from Germany and Australia. The relative abundances of MLS resistance genes in the SPM wastewater treatment system were higher than those in the above systems. According to the results in this study, the total relative abundance of MLS resistance genes in the SPM wastewater treatment system was 1.4-2.3 logs higher than those in control systems and the SPM fermentation residue. Similarly, our previous work found more abundant tet genes in an oxytetracycline wastewater treatment system than those reported in sewage treatment systems (Liu et al., 2012). Compared to OTC, SPM with higher molecular weight $\left(\mathrm{MW}_{\mathrm{SPM}}=843.0\right.$, $\left.\mathrm{MW}_{\text {отс }}=460.4\right)$ is more difficult to attack enteric and other gram-negative bacteria because their outer cell membrane acts as a strong permeability barrier (Iacoviello and Zinner, 2002). However, MLS resistance genes were obviously selected in aerobic sludge that was dominated with gramnegative bacteria.

As a matter of fact, six of the eight detected MLS resistance genes (except for erm(T) and erm(X)) have been frequently reported in a wide range of gram-negative bacteria from human and animal origins (http://faculty.washington.edu/marilynr/). It was even reported that MLS genes occurred more frequently in gram-negative bacteria $(78 \%)$ than in gram-positive bacteria (36\%) isolated from healthy population exposed to low antibiotic levels (Luna et al., 2002; Ojo et al., 2004). Horizontal gene transfer among gram-positive and gram-negative bacteria might be partly responsible for the high abundance of MLS resistance genes in aerobic sludge dominated with gramnegative bacteria (Courvalin, 1994; Gupta et al., 2003; Ojo et al., 2006). Considering that SPM could induce significant accumulation of ARGs in aerobic sludge systems, excess sludge generated during antibiotic production wastewater treatment should be disposed carefully to control the spread of ARGs in the environment.

In aerobic sludge, the rRNA methylase genes erm(B), erm(F), and $\operatorname{erm}(\mathrm{X})$ were the most abundant, followed by enzymatic modification genes ere(A) and $m p h(B)$, with efflux genes mef(A) and $m s r(D)$ being the least abundant. In anaerobic sludge, $\operatorname{erm}(\mathrm{B}), \operatorname{erm}(\mathrm{F})$, ere $(\mathrm{A})$, and $m s r(\mathrm{D})$ were the major ones. Chen et al. (2007) and Koike et al. (2010) both found that erm(B) and $\operatorname{erm}(\mathrm{F})$ were the most abundant rRNA methylase genes in swine manure and lagoons, mainly attributed to their wide host range (34 and 24 genera, respectively) and frequent association with mobile elements (Roberts, 2004). It is noteworthy that a high relative abundance of erm $(\mathrm{X})$ was observed in aerobic sludge, despite its limited host bacteria (6 genera affiliated to Actinobacteria) (http://faculty.washington.edu/ marilynr/) and low abundance in swine manure and lagoons (Chen et al., 2007), implying that SPM wastewater treatment system contained more diverse host bacteria for erm(X) than other environments.

The esterase gene ere(A) and phosphorylase gene $m p h(B)$, which are mainly harbored by gram-negative bacteria (http:// faculty.washington.edu/marilynr/), showed high abundances in aerobic sludge. Esterase genes in Enterobacteria and Pseudomonas led to SPM resistance and could biodegrade erythromycin by hydrolysis of the lactone ring (Arthur et al., 1987; Kim et al., 2004). mph(B) was reported to inactivate both 14membered and 16-membered macrolides by phosphorylation of the 2-hydroxyl group of amino sugar (Achard et al., 2008; Chesneau et al., 2007). Thus, the high abundance of these genes indicated possible biodegradation of SPM.

It is believed to be cost-efficient for bacteria to evolve membrane transporters to achieve multi-drug resistance (Martinez et al., 2009). Our previous study showed the dominance of efflux tet genes (tet(A), tet(C), and tet(G)) in aerobic sludge from OTC wastewater treatment systems (Liu et al., 2012). However, efflux MLS resistance genes mef(A) and $m s r(D)$, which often occur together in a wide range of host bacteria (28 and 22 genera, respectively, among which 21 and 17 genera belong to gramnegative bacteria), showed unexpectedly low abundance in the aerobic sludge from the SPM wastewater treatment system. Different distributions of MLS resistance genes and tet genes may be partly attributed to the different chemical structures and molecular weights of SPM and OTC.

The most interesting result was that the relative abundances of most MLS resistance genes were lower in the anaerobic sludge than those in the aerobic sludge, although anaerobic sludge was exposed to higher SPM levels. Similar conditions were found in sludge digestion, where anaerobic digestion outperformed aerobic sludge in reducing tetracycline resistance genes and Class 1 integron (Diehl and Lapara, 2010). ARGs proliferate by vertical evolution and horizontal transfer. The slow bacterial growth rate and low biomass yield in anaerobic sludge (Lettinga, 1995) could restrict the mutation during cell reproduction (i.e. vertical evolution). As for gene acquisition by horizontal transfer, the relative abundances of mobile elements (intI1 and ISCR1) in anaerobic sludge were approximately two orders lower than those in aerobic sludge (Table A7), which means gene transfer in anaerobic sludge may not be as significant as that in aerobic sludge. Similarly, Rysz et al. (2013) reported that higher oxygen availability enhanced resistance plasmid (another sort of mobile element) maintenance in pure cultured bacteria because aerobic condition eased the metabolic burden of plasmid reproduction. Less accumulation of ARGs in anaerobic sludge than in aerobic sludge suggests the merit of employing anaerobic digestion in treating antibiotic production wastewater, though the mechanism requires more study.

Significant positive correlations were found between intI1 and five most abundant MLS resistance genes (erm(B), erm(F), $\operatorname{erm}(\mathrm{X})$, ere(A), and $m p h(\mathrm{~B}))$ for all sludge samples in the SPM wastewater treatment system $\left(r^{2}=0.74,0.92,0.97,0.88,0.93\right.$; $P<0.05)$ (Fig. 4), indicating the important roles of intI1 in their proliferation. Similar conditions were reported between intI1 and tetracycline and sulfonamide resistance genes (Liu et al., 2012; Wang et al., 2014). intI1, which integrates and transfers ARGs via gene cassettes, is the most prevalent mobile element in all kinds of environments (Gillings et al., 2008). ere(A) was reported as the gene cassette of intI1 in Vibrio cholera (Thungapathra et al., 2002). Though other MLS resistance genes were seldom found as gene cassettes of intI1, intI1 could promote their proliferation in other ways. Inserting sequence common regions (ISCR) is a newly highlighted complex 

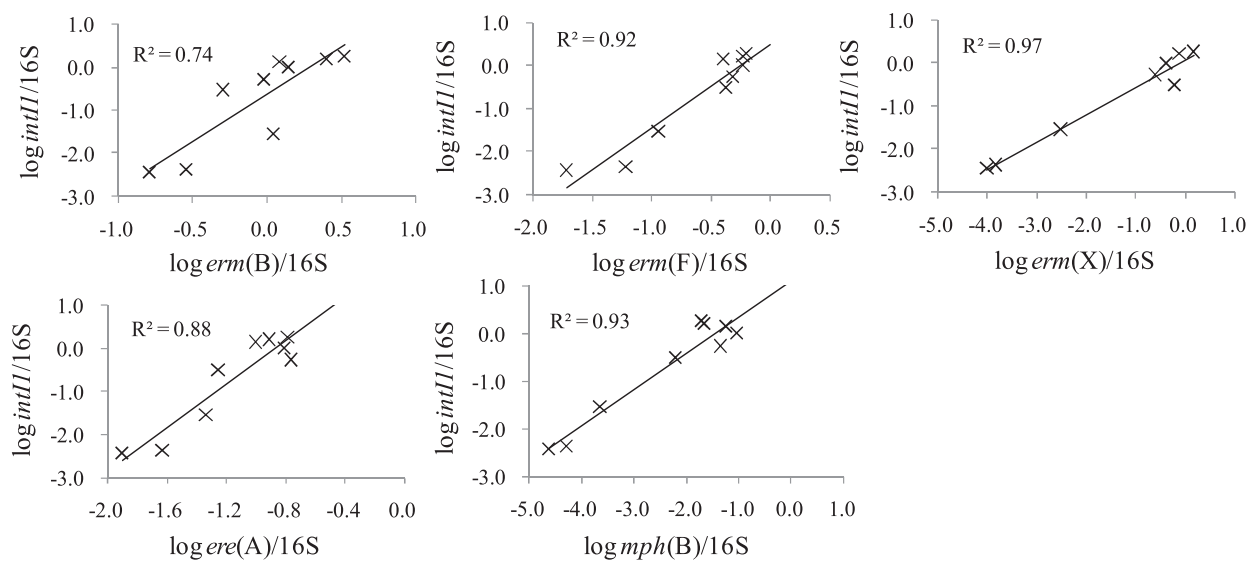

$\log \operatorname{erm}(\mathrm{X}) / 16 \mathrm{~S}$
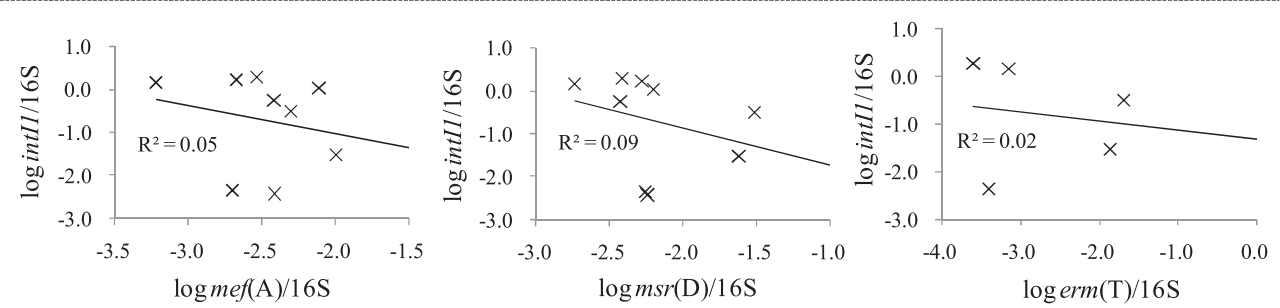

Fig. 4 - Correlations between MLS resistance genes and intI1 in sludge samples from SPM wastewater treatment systems.

integron element which can integrate non-cassette resistance genes, in which an erm gene was reported (Liu et al., 2012; Toleman et al., 2006). ISCR1, the first group of ISCR, was quantified and showed positive correlations with erm(F), $\operatorname{erm}(\mathrm{X})$, and $m p h(B)\left(r^{2}=0.65,0.68,0.71, P<0.05\right)$ (Fig. A3). Still, direct demonstration of the potential roles of intI1 and ISCR in the proliferation of these ARGs is required.

According to the phylogenetic analysis of the most diverse gene ere(A), activated sludge samples from SPM wastewater, sewage, and inosine wastewater treatment systems shared the same dominant gene type of ere(A), implying that different SPM selection pressures did not impact the phylogenetic distribution of MLS resistance genes though it impacted their abundances. However, anaerobic sludge had a different dominant ere(A) gene type, which may be attributed to different host bacteria and different accumulation pathways therein.

\section{Conclusion}

In this study, MLS resistance genes were investigated in a biological SPM wastewater treatment system with anaerobic and aerobic units. The SPM wastewater treatment system produced significantly more MLS resistance genes than other systems both in this study and in previous reports, suggesting SPM wastewater treatment system is another important source of ARG pollution. The total relative abundance of MLS resistance genes was lower in anaerobic sludge than that in aerobic sludge, suggesting the merit of enhancing anaerobic digestion during antibiotic wastewater treatment. The most abundant MLS resistance genes in the aerobic sludge were rRNA methylase genes erm(B), erm (F), and erm(X), followed by esterase gene ere(A) and phosphorylase gene $\mathrm{mph}(\mathrm{B})$, while the major genes in anaerobic sludge were erm(B), erm(F), ere (A), and $m s r(D)$. All the above genes except for $m s r(D)$ were positively correlated with intI1, implying the potential role of horizontal transfer in their proliferation. Different phylogenetic distributions of ere(A) were found in anaerobic and aerobic sludge, implying that MLS resistance genes may proliferate in different mechanisms under anaerobic and aerobic environment.

\section{Acknowledgments}

This study was supported by the National Natural Scientific Foundation of China (NSFC-21277162) and the Ministry of Science and Technology, the People's Republic of China (2012AA063401 and 2013DFG50150). We thank Ms. Li Mingyue for her kind help in sampling.

\section{Appendix A. Supplementary data}

Supplementary data related to this article can be found at http://dx.doi.org/10.1016/j.watres.2014.05.045.

\section{R E F E R E N C E S}

Achard, A., Guérin-Faublée, V., Pichereau, V., Villers, C., Leclercq, R., 2008. Emergence of macrolide resistance gene $\mathrm{mph}(\mathrm{B})$ in Streptococcus uberis and cooperative effects with rdmC-like gene. Antimicrob. Agents Chemother. 52 (8), 2767-2770. http://dx.doi.org/10.1128/AAC.00481-08.

Arthur, M., Brisson-Noel, A., Courvalin, P., 1987. Origin and evolution of genes specifying resistance to macrolide, lincosamide and streptogramin antibiotics: data and 
hypotheses. J. Antimicrob. Chemother. 20 (6), 783-802. http:// dx.doi.org/10.1093/jac/20.6.783.

Chen, J., Yu, Z., Michel Jr., F.C., Wittum, T., Morrison, M., 2007. Development and application of real-time PCR assays for quantification of erm genes conferring resistance to Macrolides-Lincosamides-Streptogramin B in livestock manure and manure management systems. Appl. Environ. Microbiol. 73 (14), 4407-4416. http://dx.doi.org/10.1128/ AEM.02799-06.

Chesneau, O., Tsvetkova, K., Courvalin, P., 2007. Resistance phenotypes conferred by macrolide phosphotransferases. FEMS Microbiol. Lett. 269 (2), 317-322. http://dx.doi.org/ 10.1111/j.1574-6968.2007.00643.x.

Courvalin, P., 1994. Transfer of antibiotic resistance genes between gram-positive and gram-negative bacteria. Antimicrob. Agents Chemother. 38 (7), 1447-1451.

Diehl, D.L., Lapara, T.M., 2010. Effect of temperature on the fate of genes encoding tetracycline resistance and the integrase of class 1 integrons within anaerobic and aerobic digesters treating municipal wastewater solids. Environ. Sci. Technol. 44 (23), 9128-9133. http://dx.doi.org/10.1021/ es102765a.

Gillings, M., Boucher, Y., Labbate, M., Holmes, A., Krishnan, S., Holley, M., Stokes, H., 2008. The evolution of class 1 integrons and the rise of antibiotic resistance. J. Bacteriol. 190 (14), 5095-5100. http://dx.doi.org/10.1128/JB.00152-08.

Gupta, A., Vlamakis, H., Shoemaker, N., Salyers, A.A., 2003. A new bacteroides conjugative transposon that carries an ermB gene. Appl. Environ. Microbiol. 69 (11), 6455-6463. http://dx.doi.org/ 10.1128/AEM.69.11.6455-6463.2003.

Iacoviello, V.R., Zinner, S.H., 2002. Macrolides: a clinical overview. In: Schonfeld, W., Kirst, H.A. (Eds.), Macrolide Antibiotics. Boston Birkhauser, Berlin, pp. 15-24.

Kim, Y.H., Pak, K., Pothuluri, J.V., Cerniglia, C.E., 2004. Mineralization of erythromycin A in aquaculture sediments. FEMS Microbiol. Lett. 234 (1), 169-175. http://dx.doi.org/ 10.1016/j.femsle.2004.03.027.

Koike, S., Krapac, I.G., Oliver, H.D., Yannarell, A.C., CheeSanford, J.C., Aminov, R.I., Mackie, R.I., 2007. Monitoring and source tracking of tetracycline resistance genes in lagoons and groundwater adjacent to swine production facilities over a 3-year period. Appl. Environ. Microbiol. 73 (15), 4813-4823. http://dx.doi.org/10.1128/AEM.00665-07.

Koike, S., Aminov, R.I., Yannarell, A.C., Gans, H.D., Krapac, I.G., Chee-Sanford, J.C., Mackie, R.I., 2010. Molecular ecology of Macrolide-Lincosamide- Streptogramin B methylases in waste lagoons and subsurface waters associated with swine production. Microb. Ecol. 59 (3), 487-498. http://dx.doi.org/ 10.1007/s00248-009-9610-0.

Larsson, D.G.J., de Pedro, C., Paxeus, N., 2007. Effluent from drug manufactures contains extremely high levels of pharmaceuticals. J. Hazard. Mater. 148 (3), 751-755. http:// dx.doi.org/10.1016/j.jhazmat.2007.07.008.

Lettinga, G., 1995. Anaerobic digestion and wastewater treatment systems. Ant. Van Leeuwenhoek 67 (1), 3-28.

Li, D., Yu, T., Zhang, Y., Yang, M., Li, Z., Liu, M.M., Qi, R., 2010. Antibiotic resistance characteristics of environmental bacteria from an oxytetracycline production wastewater treatment plant and the receiving river. Appl. Environ. Microbiol. 76 (11), 3444-3451. http://dx.doi.org/10.1128/AEM.02964-09.

Liu, M., Zhang, Y., Yang, M., Tian, Z., Ren, L., Zhang, S., 2012. Abundance and distribution of tetracycline resistance genes and mobile elements in an oxytetracycline production wastewater treatment system. Environ. Sci. Technol. 46 (14), 7551-7557. http://dx.doi.org/10.1021/es301145m.

Luna, V.A., Heiken, M., Judge, K., Ulep, C., Van Kirk, N., Luis, H., Bernardo, M., Leitao, J., Roberts, M.C., 2002. Distribution of mef (A) in gram-positive bacteria from healthy Portuguese children. Antimicrob. Agents Chemother. 46 (8), 2513-2517. http://dx.doi.org/10.1128/AAC.46.8.2513-2517.2002.

Ma, W.L., Qi, R., Zhang, Y., Wang, J., Liang, C.Z., Yang, M., 2009. Performance of a successive hydrolysis, denitrification and nitrification system for simultaneous removal of COD and nitrogen from terramycin production wastewater. Biochem. Eng. J. 45 (1), 30-34. http://dx.doi.org/10.1016/ j.bej.2009.02.001.

Marti, E., Jofre, J., Balcazar, J.L., 2013. Prevalence of antibiotic resistance genes and bacterial community composition in a river influenced by a wastewater treatment plant. PLOS One 8 (10), e78906. http://dx.doi.org/10.1371/journal.pone.0078906.

Martinez, J.L., Sánchez, M.B., Martínez-Solano, L., Hernandez, A., Garmendia, L., Fajardo, A., Alvarez-Ortega, C., 2009. Functional role of bacterial multidrug efflux pumps in microbial natural ecosystems. FEMS Microbiol. Rev. 33 (2), 430-449. http:// dx.doi.org/10.1111/j.1574-6976.2008.00157.x.

Munir, M., Wong, K., Xagoraraki, I., 2011. Release of antibiotic resistant bacteria and genes in the effluent and biosolids of five wastewater utilities in Michigan. Water Res. 45 (2), 681-693. http://dx.doi.org/10.1016/j.watres.2010.08.033.

Negreanu, Y., Pasternak, Z., Jurkevitch, E., Cytryn, E., 2012. Impact of treated wastewater irrigation on antibiotic resistance in agricultural soils. Environ. Sci. Technol. 46 (9), 4800-4808. http://dx.doi.org/10.1021/es204665b.

Ojo, K., Ulep, C., Van Kirk, N., Luis, H., Bernardo, M., Leitao, J., Roberts, M., 2004. The mef (A) gene predominates among seven macrolide resistance genes identified in gram-negative strains representing 13 genera, isolated from healthy Portuguese children. Antimicrob. Agents Chemother. 48 (9), 3451-3456. http://dx.doi.org/10.1128/ AAC.48.9.3451-3456.2004.

Ojo, K.K., Ruehlen, N.L., Close, N.S., Luis, H., Bernardo, M., Leitao, J., Roberts, M.C., 2006. The presence of a conjugative gram-positive Tn2009 in gram-negative commensal bacteria. J. Antimicrob. Chemother. 57 (6), 1065-1069. http://dx.doi.org/ 10.1093/jac/dkl094.

Roberts, M.C., 2004. Resistance to macrolide, lincosamide, streptogramin, ketolide, and oxazolidinone antibiotics. Mol. Biotechnol. 28 (1), 47-62. http://dx.doi.org/10.1385/MB:28:1:47. Roberts, M.C., Sutcliffe, J., Courvalin, P., Jensen, L.B., Rood, J., Seppala, H., 1999. Nomenclature for macrolide and MacrolideLincosamide-Streptogramin B resistance determinants. Antimicrob. Agents Chemother. 43 (12), 2823-2830.

Rysz, M., Mansfield, W.R., Fortner, D.J., Alvarez, J.J.P., 2013. Tetracycline resistance gene maintenance under varying bacterial growth rate, substrate and oxygen availability, and tetracycline concentration. Environ. Sci. Technol. 47, 6995-7001. http://dx.doi.org/10.1021/es3035329.

Stoll, C., Sidhu, J.P.S., Tiehm, A., Toze, S., 2012. Prevalence of clinically relevant antibiotic resistance genes in surface water samples collected from Germany and Australia. Environ. Sci. Technol. 46, 9716-9726. http://dx.doi.org/10.1021/es302020s.

Sutcliffe, J.A., Leclercq, R., 2002. Mechanisms of resistance to macrolides, lincosamides, and ketolides. In: Schonfeld, W., Kirst, H.A. (Eds.), Macrolide Antibiotics. Boston Birkhauser, Berlin, pp. 281-317.

Thungapathra, M., Sinha, K.K., Chaudhuri, S.R., Garg, P., Ramamurthy, T., Nair, G.B., Ghosh, A., 2002. Occurrence of antibiotic resistance gene cassettes aac $\left(6^{\prime}\right)$-Ib, dfrA5, dfrA12, and ereA2 in class I integrons in non-O1, non-O139 vibrio cholerae strains in India. Antimicrob. Agents Chemother. 46 (9), 2948-2955. http://dx.doi.org/10.1128/ AAC.46.9.2948-2955.2002.

Toleman, M.A., Bennett, P.M., Walsh, T.R., 2006. ISCR elements: novel gene-capturing systems of the 21st century? Microbiol. Mol. Biol. Rev. 70 (2), 296-316. http://dx.doi.org/10.1128/ MMBR.00048-05. 
Wang, F.H., Qiao, M., Lv, Z-e., Guo, G.X., Jia, Y., Su, Y.H., Zhu, Y.G., 2014. Impact of reclaimed water irrigation on antibiotic resistance in public parks, Beijing, China. Environ. Pollut. 184, 247-253. http://dx.doi.org/10.1016/j.envpol.2013.08.038.

Wei, F.S., 2002. Monitoring and Analysis Methods of Water and Wastewater, fourth ed. Chinese Environmental Sciences Publishment, China.
Zhang, Y., Xie, J.P., Liu, M.M., Tian, Z., He, Z.L., van Nostrand, J.D., Ren, L.R., Zhou, J.Z., Yang, M., 2013. Microbial community functional structure in response to antibiotics in pharmaceutical wastewater treatment systems. Water Res. 47 (16), 6298-6308. http://dx.doi.org/ 10.1016/j.watres.2013.08.003. 